\title{
Will the European Union Europeanise the Balkans to Avoid the Balkanisation of Europe?
}

\begin{abstract}
The purpose of this paper is to examine and analyse the appropriate modalities for the process of the Europeanisation of the countries from the Balkans, inter alia, for the need to avoid the Balkanisation of Europe, bearing in mind all the aspects. The effects of these processes can be disseminated into two directions, EU-Balkans and vice versa, so the main point is to explore the common spots and to use them in the EU's accession path of the Balkan countries.

Due to the character of the paper, the most frequently used methods will be the descriptive method, the content analysis method and the comparative method.
\end{abstract}

Keywords: European Union, Balkans, Integration, Accession

\section{Introduction}

The contemporary challenges which the European Union is faced with reflect on the accession process of the countries from the Western Balkans. Financial, migration, ecological and other problems are at the top of the EU agenda, thereby pushing the enlargement process to the bottom of the list of priorities. However, it doesn't mean that the Europeanisation of the Balkans should stop, but continue in parallel with the resolving of problematic issues.

\footnotetext{
^ Mladen Karadzoski - University of "St. Kliment Ohridski" - Bitola, e-mail: mladenkaradzoski1983@gmail.com, ORCID: 0000-0002-1942-1804.

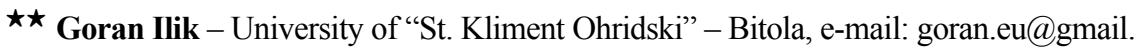
com, ORCID: 0000-0003-3501-1386.
} 
The opposite process of the Europeanisation of Balkans is the Balkanisation of Europe, which is usually interpreted as a very negative phenomenon, so EU is trying to avoid its import. However, it is probable that the most successful modality for avoiding the Balkanisation of Europe is actually the Europeanisation of the Balkans, but not only in a nominal sense, but in an essential and concrete one. It comprises not only the adopting of laws and rules, but also the adoption of European common values such as the rule of law, democracy, respect for human rights, the fight against corruption, total transparency, effectiveness, efficiency etc.

All of this can be achieved with large-scale EU help for the Balkan countries, not only that of a financial, logistic, legal and administrative nature, but also cultural and educational help. The Europeanisation of the Balkans should continue at full speed because otherwise, the opposite process of the Balkanisation of Europe will harm the civil and cultural achievements of the continent.

The European Union will be complete as a geographical entity only when all the Balkan countries are part of it. Until then, but even after that, the process of the Europeanisation of Balkans, in the widest sense of the word, should have full continuity and effectiveness.

\section{A Definition and Clarification of the Terms 'Europeanisation' and 'Balkanisation'}

Broadly speaking, the concept of Europeanisation was reintroduced to refer to a set of processes through which EU political, social and economic dynamics become part of the logic of domestic discourse, identities, political structures and public policies. ${ }^{1}$ However, the EU impact on countries with different politico-economic and social systems, more specifically on the post-communist European countries in transition, remained vastly unexplored. Once the Eastern bloc collapsed, considerable differences surfaced among these countries. However, the vast majority of them shared the common aspiration of EU membership, because they consider it as a condition sine qua non for democratic development, but also for economic progress and cultural achievements.

The European Union represents a paradigm for modernization of politi$\mathrm{cal}$, economic and social systems ${ }^{2}$ of candidate and potential candidate states for accession to the Union, and the process of Europeanisation is actually a group of steps which lead to systemic convergence through the processes

1 C. Radaelli, Wither Europeanisation? Concept Stretching and Substantive Change, Political Studies Association Annual conference, London 2000.

2 P.C. Ioakimides, European Union and the Greek State, Themelio, Athens 1998. 
of democratisation, marketisation, stabilisation and institutional inclusion. Two of the most important variables which result from the process of Europeanisation of Balkans are: a) the mechanisms of Europeanisation, and b) the confining conditions within the region and within each Balkan state.

a) The mechanisms of Europeanisation: There is a big variety of mechanisms used in this process and they have a different impact and influence in each of the countries, but also there is diversification in the areas where the mechanisms are applied. So, they can generate either accepting, non-accepting or partly accepting of the mechanisms (i.e. rules, suggestions, standards, recommendations) by the Balkan states.

Keeping in mind the background of these states, the Europeanisation mechanisms which can be discerned are the following (borrowing from democratisation theories' terminology $y^{3}$ and combining it with Europeanisation approaches' typologies) ${ }^{4}$ :

Coercion: i) Control (promotion through specific policies supported by positive and negative sanctions) ii) Conditionality (the deliberate use of coercion by attaching specific conditions to the distribution of benefits).

Mimetism: i) Contagion (the dissemination of experience through neutral channels) ii) Consent (interaction between international processes and domestic groups that create expectations from below).

b) Confining conditions: In accordance with Kirchheimer's terminology, confining conditions refer to those conditions that hinder human action and have to be overcome for breakthroughs, conceived as environments facilitating, if not maximizing, the room for choice to occur. These confining conditions can be grouped into the following categories:

Structural: emerging form the nature of the whole society in its historical development.

Transitional: Stemming from the nature of the recent transformation between two social systems.

Systemic: Characterising the given social system dominating the state concerned.

State-Building/Nation-Formation: Establishing a new state with internationally recognized borders or even a new nation. ${ }^{5}$

${ }^{3}$ P. Schmitter, The influence of the international context upon the choice of national institutions and policies in neo-democracies, in: The International Dimensions of Democratization - Europe and the Americas, ed. L. Whitehead, Oxford University Press, Oxford 1996, pp. 26-54.

4 C. Radaelli, op. cit.

5 L. Demetropoulou, Europe and the Balkans: Membership Aspiration, EU Involvement and Europeanisation Capacity in South Eastern Europe, "Southeast European Politics", Vol. 3, No. 2-3/2002, pp. 89-90. 
Since the fall of communism in the 1990s, the Western Balkans have been undergoing fundamental and multiple transformations that are complex in their nature and difficult to explain through a single paradigm or model. Such a complex transformation, where democratisation and transition take place in conjunction with nation and state building and European integration, usually comes at the expense of a truncated picture of the region. The focus has shifted towards the Western Balkans integration into the EU, employing so the enlargement literature. ${ }^{6}$ There was a "no alternative for the EU" perception in all Western Balkan states, so their integration towards the European Union was introduced as one of the main strategic goals in each of them.

The Europeanisation of the Balkans means not only ensuring the compatibility of the models of democracy of Balkan states with Western ones, but also the creation of pre-conditions for stability and development.

A review of the national legislation and harmonization with the acquis communautaire will help Balkan countries not only to approximate their administrative systems, but also to accept European values, standards, criteria, mentality and cultural values. As a result of all these reform processes, the Balkan countries will gain huge qualitative transformations. ${ }^{7}$

The term "Balkan" comes from a Turkish word meaning "a chain of wooded mountains". The Balkan Peninsula may be defined as an area of Southeastern Europe surrounded by water on three sides: the Adriatic Sea to the west, the Mediterranean Sea (including the Ionian and Aegean seas) to the south and the Black Sea to the east. Its northern boundary is often given as the Danube, Sava and Kupa/Kolpa rivers. ${ }^{8}$

This term "The Balkans" covers not only those countries which lie within the boundaries of the "Balkan Peninsula", but also include Slovenia, and Romania. Slovenia, which was part of Yugoslavia from 1919 to 1991, lies partially north of the Danube-Sava line and therefore outside the Peninsula, but prior to 1991 the whole of Yugoslavia was considered to be part of the Balkans. In most of the English-speaking world, the countries commonly included in the Balkan region are: Albania, Bosnia and Herzegovina, Bulgaria, Croatia, Greece, Macedonia

${ }^{6}$ T. Radovanovik, From Balkanisation to Europeanisation of the Balkan Countries, “American International Journal on Contemporary Research", Vol. 2, No. 4/2012, p. 208.

7 O. Anastasakis, The Europeanisation of the Balkans, "The Brown Journal of World Affairs", No. XII (1)/2005, p. 80.

8 S. Adu-Gyamfi et al., The Balkans and the European Union, "Epiphany: Journal of Transdisciplinary Studies", Vol. 9, No. 2/2016, p. 95. 
(North Macedonia), Montenegro and Serbia. Other countries sometimes included are Moldova, Romania, Slovenia, and Turkey.

While Balkanisation is a term used to describe the concept of division or disintegration of coexistent things from a micro-level such as family or neighbourhood to a macro-level such as state institutions, Europeanisation is used in terms of integration or domestic adaptation. Europeanisation is expected from Europe. In a chapter entitled "Why the EU Needs Croatia (even more than Croatia needs the EU)" of his book „What Does Europe Want?" (written together with Slavoj Žižek), Croatian philosopher Srećko Horvat quotes a sentence from El Pais (2 May 2004); „By joining the EU, Slovenia escaped the Balkan curse". But if we take a closer look, Europe is "Balkanised" already, and, on the other hand, the Balkans are "Europeanised" as well, he adds. After 14 years of EU Accession on Slovenia's part, a right-wing populist party won the most votes for a second time in Slovenian polls thanks to an anti-migration discourse. While the EU was taking down walls towards the WBCs with the liberalisation of the EU's visa regime towards them, Hungary, an EU member state, built a wall along the EU country's border with Western Balkans during the socalled European migrant crisis. ${ }^{9}$ Therefore, we have to note that these two processes can move in parallel, but can also shift in opposite directions.

The Yugoslav Wars broke out at a time when the fall of the Berlin Wall, the revolutions in Eastern Europe and the dissolution of the Eastern Bloc had instilled a sense of hope that Europe would be whole and free, and that the history of European wars was coming to a close, heralding a millennium of peace and democracy. The crisis and the breakup of the former Yugoslavia in the 1990s "re-balkanised" Southeast Europe and revived old Western stereotypes about the Balkans and Balkanisation. According to Western observers, the crisis in the Balkans had brought wars back to Europe and, instead of Europeanising the Balkans, threatened to "balkanise" Europe. This gave rise to a proliferation of studies in the West about the Balkans. Some, by reinterpreting or rewriting history, proposed or justified political and military solutions for the Balkan crisis, while others sought to elucidate the history of the Balkans and to explain the "balkanisation" phenomenon. The first group of authors considers the Balkans as a European periphery (sometimes called as "Savage Europe") which threatens the entire continent with its endless mutual conflicts. Therefore, according to them, the task of the great powers is to impose on the Balkans, by force if necessary, the rules of civilised behaviour, or else risk seeing the Balkan conflicts spill over into the entire continent,

9 A.S. Gozubenli, N. Tekeshanoska, Europeanisation of the Balkans vs Balkanisation of Europe: A Vision Limited by Realities, UBT International Conference, 2018, p. 6. 
as was the case with World War I. ${ }^{10}$ But, the other option, i.e. using the European Union soft power should be taken into account, so this process can be conducted in a more sophisticated manner.

Undoubtedly, the war in former Yugoslavia in the early 1990s was the eruption of those centuries-old ethno-religious antagonism and discontents. From the rule of the erstwhile Ottoman and Habsburg Empires to that of the Socialist Federal Republic of Yugoslavia (SFRY), the history of the Balkan Peninsula - or what is now often called Southeastern Europe - was seemingly sacrificed to this inexorable negative path dependency, namely called with a political science term: Balkanisation. In other words, the entirety of 20th century Balkan history is defined by the emergence and strengthening of Balkan national self-identities connected to the conflicts surrounding the decline and fall of the multiethnic Ottoman and Habsburg Empires prior to and after the First World War. Referencing this phenomenon, the term Balkanisation has been used to describe more generally traumatic violence-producing ethnic conflicts of new state formations that occur as a result of imperial and/or federal disintegrations. Thus, the term is used to define fragmentation into mutually hostile entities and conflicts between them as the opposite of the integration process and has been one of the most negative paradigms in international relations since the First World War onwards. ${ }^{11}$

With respect to this long-term history of inter-ethnic antagonism, the painful disintegration of SFRY can be regarded as a form of political dejavu which recalls early 20th century Balkanisation. For that reason, one might say the fall of former Yugoslavia was the second period of Balkanisation in the region. This conflict-producing, nation-building process undeniably changed the European geographic and ideological maps again by the advent of the new century. Since Yugoslavia was totally dissolved, seven new independent states have emerged so far from the wreckage of the Titoist federation. These are Serbia, Croatia, BosniaHerzegovina, Slovenia, Macedonia (North Macedonia), Montenegro and finally Kosovo. ${ }^{12}$

10 P. Simic, Balkans and Balkanisation: Western Perceptions of the Balkans in the Carnegie Commission's Reports on the Balkan Wars from 1914 to 1996, "PERCEPTIONS", Vol. XVIII, No. 2/2013, pp. 113-114.

11 E. Yalinkilicli, From Neo-Balkanisation to Europeanisation: Institutional Change and Regional Cooperation in The Western Balkans, "Balkan Araştırma Enstitüsü Dergisi", Vol. 3, No. 2/2014, pp. 128-129.

12 T. Gallagher, Outcast Europe, The Balkans, 1789-1989: From the Ottomans to Milošević, Routledge, London and New York 2001, p. 2. 


\section{Current Situation and Trends for the Process of the 'Europeanisation of the Balkans'}

To reduce the discomfort of the outlined simplification of the relationship between the EU and the Western Balkans which can be found in literature and which focuses on processes of Europeanisation in the region, it should be noted that the sentiment of "the long journey home"13 has been widely embraced and disseminated by the political elites of the region as well. "Western-led-and-funded institutions functioned as important channels for the creation and reproduction of a pro-Western elite in post-socialist Europe". ${ }^{14}$ Pro-Western loyalty has also been home-grown. Slovenia is a most handy case to observe the rise of the "EU emotion" which, in critical writing, has been defined as bridging collective neurosis, or EUrosis, ${ }^{15}$ producing a domino-effect of "nested Orientalisms" towards the Balkans ${ }^{16}$ and the fantasy of a "civilisational mission" that the Slovene nation has to perform in the region. The fantasy element of local and national engagement in the transnational politics of EU integration and Europeanisation throws light on the complex and complicit architecture by which the most current structures of knowledge power in the EU are being defined. It also unveils, albeit unwittingly, the desire to "harmonise" the EU into the image of Europe which continues to be fashioned in Western-centric terms. This is most evident in the revival of the idea of Central Europe as a cradle of European identity, raised in the traditions of Christianity and humanism. Notwithstanding how this selective memory obscures the legacies of Mitteleuropa as a cosmopolitan and multicultural pool of identification, ${ }^{17}$ the historical reclaiming of the Central European identity as "Western" at its heart, serves the ideological function of (re) producing mythologies of Europe by which Europe's "others" can also be excluded from mytho-historic and real communities of belonging in the new post-socialist states. Whereby the desire to bring the reality (of the $\mathrm{EU}$ ) to a projection ("Europe") may be a legitimate one, it is questionable

${ }_{13}$ T. Petrovic, The Long Journey to Home: Representation of Western Balkans in the political and media discourse, Mirovni inštitut, Ljubljana 2009.

14 S. Jansen, Cosmopolitan openings and closures in post-Yugoslav antinationalism, in: Cosmopolitanism in practice, eds. M. Novicka, M. Rovisco, Ashgate, Aldershot 2008, p. 86.

15 M. Velikonja, Eurosis - Critics of the new Eurocentrism, Mirovni inštitut, Ljubljana 2005.

${ }^{16}$ S. Zizek, Caught in Another's Dream in Bosnia, in: Why Bosnia: Writings on the Balkan War, eds. R. Ali, W. Lifschulz, Pamphleteer's Press, Stony Creek 1993, pp. 233-240.

17 K.V. Horvat, K. Delanty, Mitteleuropa and the European Heritage, "European Journal of Social Theory", Vol. 11, No. 2/2008, pp. 203-218. 
whether it can succeed in the effort. In the analysis which follows, we provide arguments for debate concerning this effort. In particular, we point to a number of theoretical limitations in the plan to harmonise the national politics of identity with the transnational politics of the EU based on pre-assumed notions of a "shared understanding." Instead, we argue that, firstly, the process of harmonisation can be successfully governed only if and when local histories of identity have a channel into the conceptual map of Europeanisation of identity; and secondly, when these histories, and the memories of them are taken into consideration as vital to democratisation and pluralisation of the Europeanisation agenda. ${ }^{18}$ We think that inclusion instead of underestimation will help the Europeanisation process for these countries, and also help the maintenance of peace and democracy across the whole of Europe.

The agenda of Europeanisation is also defined by the specificities of particular cases and takes the form of short, medium, and long-term objectives on political, social, economic, security, and technical matters. In South East Europe, the EU agenda includes security and peace-building issues, border questions, reconstruction and development, and a postcommunist transition and association agenda. Never before has the EU been engaged in such a wide variety of issues when dealing with candidate or potential candidate countries. The fact that the Balkan countries begin with a weaker capacity than previous candidate countries has made handling the EU agenda more difficult. For its part, the EU has to stick to its designated agenda; to keep the same rules and standards for all the countries in order to protect its own achievements of economic and political integration.

These transition processes were not only related to the security sphere, but also to the contemporary challenges arising from the new political and economic constellation. The implementation of a liberal democracy system was imperative for all Balkan countries, but so was the creation of functional market economies, a system of realistic social benefits for the citizens and a synergy between the state and the citizen.

Structural weaknesses in the public administration and judiciary systems, as well as the "heritage" from the communist era were still very big obstacles for the process of the Europeanisation of Balkans, especially when it comes to accepting "European values, standards and criteria".

Sometimes there was an explicitly manifested political will for the implementation of the required reforms, but there was a lack of financial

${ }_{18}$ K.V. Horvat, D. Mandelic, Some conceptual problems in tracking the influence of Europeanisation in South Eastern Europe: the case of the ex-Yugoslav Balkan region, in: Changing Identities in South Eastern Europe, ed. H. Scheck, ASO, Ljubljana 2012, pp. 16-17. 
and administrative capabilities, ${ }^{19}$ or vice vers $;$; if the institutional capacities were good, there was a lack of political will and political consensus.

The EU enlargement plan for the WBCs entitled "The Credible Enlargement Perspective for the Western Balkans" was presented by the European Commission in February 2018. The new strategy indicates the clear prospect of the accession of Western Balkans countries to the EU by the end of 2025. The date 2025 is mentioned in the strategy in the following statement: "The Strategy explains the steps that need to be taken by Montenegro and Serbia to complete the accession process in a 2025 perspective; while others could catch up, Montenegro and Serbia are the only two countries with which accession talks are already under way." In June 2018, after a lengthy debate, the EU Council agreed to open membership talks with Macedonia and Albania by the end of 2019. This perspective holds that the EU needed more time to absorb the addition of 13 new member states among the CEECs over the past decades and should not take in any new members until real and demonstrable consolidation has been achieved inside the EU.

\section{Contemporary Challenges for the "Balkanisation of Europe" Processes}

The Balkan region has been engulfed in serious controversies over the definition of nationalities and citizenship. Balkanisation and Debalkanisation have taken a swipe at the region's peace, stability and economic prosperity. The European Union is currently battling with its own challenges as Britain makes moves to dismember. In the midst of this, the Balkan region still beckons for solutions to its problem of integration. The current status of the Balkan region in the eyes of the European Union still hangs around the neck of the EU. The only "winwin" situation both for the EU and Western Balkans can be achieved not only with enormous efforts by the Balkan states, but also with major flexibility and understanding on the Union's part.

Most WBCs are today between stabilitocracy and hybrid democracies, aspiring to join the EU, while they are watching Hungarian President Viktor Orbán's illiberal tendencies inside EU borders. The European Parliament has voted to trigger the EU's most serious disciplinary procedure against Hungary, saying the country's government poses a "systematic threat" to democracy and the rule of law. Marie Le Pen who was the leader of anti-Islam and anti-immigration National Front,

19 V. Gligorov et al., Balkan Reconstruction and European Integration, The Wiiw Balkan Observatory, "Working Paper" 1999, pp. 27-28. 
won $18 \%$ of the votes in the French presidential elections in 2012. Similar parties with right-wing extremist orientations and programs exist in Austria, Switzerland, Italy, Belgium and a part of them are represented by its members in ruling coalitions. Austria came close to becoming the first EU country to elect a far-right head of state, Norbert Hofer, and the antiestablishment Five Star Movement and right-wing League have formed a coalition in Italy. The Brexit vote in the UK constitutes the first popular decision of a member state to leave the EU. ${ }^{20}$

The WBCs are scarred by important structural problems inherited from its communist past and the growing support for far-right and antiEU political movements in EU Member States makes the decision-making process regarding the accession processes of the WBCs unpredictable and volatile. The xenophobic and illiberal governments in the CEECs remind the WBCs of their autocratic practices in the past. However, the eyes of the Balkan countries should be focused on their own reforms and the achievement of the standards and criteria for EU membership, and not in the internal "political constellation" inside the European Union.

\section{Conclusions}

"Europe will not be made all at once, or according to a single plan. It will be built through concrete achievements which first create de facto solidarity", said Robert Schuman. These words said by one of the founding fathers of the European Union many decades ago, are still valuable and applicable for the contemporary EU, because "Europe is not yet fully integrated towards the European Union". Western Balkan countries are also an important and immanent part of the "European mosaic", so their accession towards EU is a condition sine qua non for the completion of the European continent.

The Europeanisation of the Balkans should be a process which is resistant to daily policies, activities and events not only in the European Union, but also in the Balkan states. It should be conducted on a regular and continuous basis not only for the benefit of all Balkan states, but also for the European Union as an entity. In contrast, the process of the Balkanisation of Europe could become a reality in each of the EU member states, and also in the EU generally.

${ }^{20}$ F. Bieber, M. Kmezić, EU enlargement in the Western Balkans in a time of uncertainty, „Policy brief, BiEPAG”, September 2016, pp. 1-16. 


\section{References}

Adu-Gyamfi S. et al., The Balkans and the European Union, "Epiphany: Journal of Transdisciplinary Studies", Vol. 9, No. 2/2016, p. 95, DOI: https://doi.org/10.21533/epiphany.v9i2.242.

Anastasakis O., The Europeanisation of the Balkans, "The Brown Journal of World Affairs", No. XII (1)/2005, p. 80.

Bieber F., Kmezić M., EU enlargement in the Western Balkans in a time of uncertainty, „Policy brief, BiEPAG”, September 2016, pp. 1-16.

Demetropoulou L., Europe and the Balkans: Membership Aspiration, EU Involvement and Europeanisation Capacity in South Eastern Europe, "Southeast European Politics", Vol. 3, No. 2-3/2002, pp. 89-90.

Demetropoulou L., European Integration and the Balkans, Conference Proceedings, 17th Annual Graduate Student Conference 'E2K: A New Vision for Europe', Institute on Western Europe, Columbia University, 2000, pp. 197-214.

Gallagher T., Outcast Europe, The Balkans, 1789-1989: From the Ottomans to Milošević, Routledge, London and New York 2001, p. 2.

Gligorov V. et al., Balkan Reconstruction and European Integration, The Wiiw Balkan Observatory, "Working Paper" 1999, pp. 27-28.

Gozubenli A.S., Tekeshanoska N., Europeanisation of the Balkans vs Balkanisation of Europe: A Vision Limited by Realities, UBT International Conference, 2018, p. 6, DOI: https://doi.org/10.33107/ubt-ic.2018.390.

Horvat K.V., Delanty K., Mitteleuropa and the European Heritage, „European Journal of Social Theory", Vol. 11, No. 2/2008, pp. 203-218, DOI: https://doi.org/10.1177/1368431007087474.

Horvat K.V., Mandelic D., Some conceptual problems in tracking the influence of Europeanisation in South Eastern Europe: the case of the ex-Yugoslav Balkan region, in: Changing Identities in South Eastern Europe, ed. H. Scheck, ASO, Ljubljana, 2012, pp. 16-17.

Ioakimides P. C., European Union and the Greek State, Themelio, Athens 1998.

Jansen S., Cosmopolitan openings and closures in post-Yugoslav antinationalism, in: M. Novicka, M. Rovisco, Cosmopolitanism in practice, Ashgate, Aldershot 2008, p. 86.

Petrovic T., The Long Fourney to Home: Representation of Western Balkans in the political and media discourse, Mirovni inštitut, Ljubljana 2009.

Radaelli C., Wither Europeanisation? Concept Stretching and Substantive Change, Political Studies Association Annual Conference, London 2000.

Radovanovik T., From Balkanisation to Europeanisation of the Balkan Countries, "American International Journal on Contemporary Research", Vol. 2, No. 4/2012, p. 208. 
Schmitter P., The influence of the international context upon the choice of national institutions and policies in neo-democracies, in: The International Dimensions of Democratization - Europe and the Americas, ed. L. Whitehead, Oxford University Press, Oxford 1996, pp. 26-54, DOI: https:// doi.org/10.1093/0199243751.003.0002.

Simic P., Balkans and Balkanisation: Western Perceptions of the Balkans in the Carnegie Commission's Reports on the Balkan Wars from 1914 to 1996, "PERCEPTIONS", Vol. XVIII, No. 2/2013, pp. 113-114.

Velikonja M., Eurosis - Critics of the new Eurocentrism, Mirovni inštitut, Ljubljana 2005.

Yalinkilicli E., From Neo-Balkanisation to Europeanisation: Institutional Change and Regional Cooperation in The Western Balkans, "Balkan Araştırma Enstitüsü Dergisi”, Vol. 3, No. 2/2014.

Zizek S., Caught in Another's Dream in Bosnia, in: Why Bosnia: Writings on the Balkan War, eds. R. Ali, W. Lifschulz, Pamphleteer's Press, Stony Creek 1993, pp. 233-240. 